\title{
Implications of Information and Communication Technologies (ICT) for School-Home Communication
}

\author{
Don Heath \\ University of Wisconsin \\ Oshkosh, Oshkosh, WI, USA \\ Drheath2@gmail.com
}

\author{
Rozan Maghrabi and Nora Carr \\ University of North Carolina \\ Greensboro, Greensboro, NC, USA \\ Romaghra@uncg.edu, \\ Carrn@gcsnc.com
}

\begin{abstract}
Research demonstrates the positive impact of parental involvement on students, families and schools. Studies also indicate a close connection between effective school-home communication and increased parental involvement and engagement in learning. Effective selection and use of Information Communication Technologies (ICT) invites more effective school-home communication, increasing parental involvement and improving student outcomes. However, ICT adoption rates are heterogeneous, influenced by cultural, socioeconomic and other factors. Also, gaps may exist between parent/school communication preferences. Our multi-case study investigates principals and parents from three different public elementary schools (suburban/high wealth; urban/low wealth; urban magnet/mixed income) to understand the impact of misalignment in ICT adoption and use on school-home communication. We find misperceptions by parents and principals regarding their ICT adoption beliefs and actual use. Our results also indicate alignment between parent and principal ICT preferences and expectations improves parent satisfaction with the principal and the school, while misalignment has the opposite effect.
\end{abstract}

Keywords: Diffusion, ICT, parent/school communication, communication efficacy

\section{Introduction}

Considerable research exists that demonstrates the positive impact of parental involvement on students, families, and schools. Parental involvement is correlated with improvement in student achievement across multiple measures, including learning outcomes, attendance, pass/fail ratios, and graduation rates, as well as behavior at home and at school (Askar, 2013; Cary, 2006; Henderson, \& Mapp, 2002; Machen, Wilson, \& Notar, 2005; Driessen, Smit \& Sleegers, 2005). These

Material published as part of this publication, either on-line or in print, is copyrighted by the Informing Science Institute. Permission to make digital or paper copy of part or all of these works for personal or classroom use is granted without fee provided that the copies are not made or distributed for profit or commercial advantage AND that copies 1) bear this notice in full and 2) give the full citation on the first page. It is permissible to abstract these works so long as credit is given. To copy in all other cases or to republish or to post on a server or to redistribute to lists requires specific permission and payment of a fee. Contact Publisher@InformingScience.org to request redistribution permission. findings are consistent across economic, racial, educational, and cultural backgrounds (Chaboudy \& Jameson, 2001; Driessen et al., 2005; Murphy, 2013). Administrators recognize the value of familial involvement in improving student outcomes, although they perpetually grapple with how to get families more actively engaged at school and at home in supporting the learning process (Cary, 2006; Henderson \& Mapp, 2002). Most 
students at every grade level also want their parents to be well-informed and involved regarding school-related issues, activities and concerns (Chaboudy \& Jameson, 2001). Moreover, research has shown that most parents desire better and more frequent communication from their children's schools, and are eager to help their children succeed in school (Cary, 2006; Henderson \& Mapp, 2002). However, many parents do not know what is expected of them, or how to access information and resources they may use to help their children experience more school success (Chaboudy \& Jameson, 2001; Henderson \& Mapp, 2002; Murphy, 2013). Others feel unwelcome at school, intimidated by school personnel, or face other barriers such as limited English proficiency, lack of transportation, limited access to technology, high mobility rates, fear of authorities due to immigration status and other concerns, or previous negative experiences with school personnel, either as students themselves, or with their children (Flessa, 2008; Wiseman, 2010).

More than 50 studies indicate a close connection between better and more frequent communications and increased levels of parental involvement and engagement in learning (Cary, 2006). Communication may be defined as a "two-way process of convergence" (Rogers, 2003, p. 6), in which information is shared by both parties and mutually beneficial relationships are forged between individuals, groups, and organizations, including schools and the families they serve. Effective communication, which entails listening and responding as well as the frequent flow of quality information, is often cited as one of the most important determinants of successful collaboration between school and home (Cary, 2006; Henderson \& Mapp, 2002). Schools are required, either by law or by the desire to maintain parent support, to keep parents up-to-date regarding student progress, homework assignments, and academic concerns as well as events such as literacy nights, choral concerts, athletic events, classroom projects, important deadlines, Parent Teacher Association (PTA) activities, and more. Principals frequently seek new ways to get parents more involved in their child's education, realizing the importance of establishing and maintaining meaningful, direct, two-way communication - a defining feature of effective parental involvement (Cary, 2006; Henderson \& Mapp, 2002; Murphy, 2013). However, principals face many challenges in maximizing the effectiveness of school communication due to cultural, socioeconomic and educational differences, language barriers, lack of trust, and other common concerns (Cary, 2006; Henderson \& Mapp, 2002). Schools must be able to manage the flow of information in the classroom between teachers and students, and also with parents at their workplace and home (Cary, 2006). Information must be clear and easily accessible, and written, spoken, or translated in language that most parents, including those with lower literacy levels, can understand (Askar, 2013). Most importantly, communication must be timely, relevant, and meet parents' needs (Cary, 2006). Yet finding appropriate communication methods to connect schools and the diverse parents they serve remains a challenge for many administrators (Cary, 2006). Smart and strategic appropriation of new information and communication technologies (ICTs) can strengthen communication, external outreach, and parent engagement (Carr, 2012).

Advanced ICTs can improve communication by providing new and more efficient ways in which "communications can be produced, distributed, displayed, and stored" (Wright, 2001, p. 6). ICTs can be defined as information, resources, applications, and services accessed via technology (Selwyn, 2004). ICTs are transforming practices and changing expectations regarding schoolhome communication. According to Pavlik (2007), these new technologies have a considerable influence on public relations.

There is growing evidence that "new technologies are enhancing, and to some degree changing, public relations roles" (Springston, 2001, p. 606). In today's mobile lifestyle, fast and short digital information exchanges and voice mail messages are replacing traditional forms of communication such as writing notes, or sending home printed fliers in student book bags. Consequently, many parents might expect to find messages regarding school activities online or via smart phones, although gaps still remain in access, primarily due to poverty, along with language barri- 
ers and some cultural differences (Lenhart, Purcell, Smith, \& Zickulu, 2010). As new online and digital communication tools become more prominent, societal expectations regarding their use is increasing (Lenhart et al., 2010; Pavlik, 2007). As a result, traditional communicative approaches may be marginalized in favor of the newer technologies. This suggests that choosing the appropriate communications technology is essential to maximize school and home communication efficacy and encourage familial involvement. Yet, technology adoption is heterogeneous. Rogers (2003) suggests high variability in the rate of diffusion of technology among individuals. ICTs chosen by principals might not align with parents' references and needs (Carr, 2012). This further complicates symmetry between communication expectations and practice.

Communication is foundational to effective school/family partnerships (Cary, 2006). Lack of communication fosters misperceptions and distrust (Cary, 2006; Bryk \& Schneider, 2002;

Tschannen-Moran, 2004). Schools frequently seek new ways to get parents more involved in their child's education, realizing the importance of building better relationships and establishing and maintaining meaningful, direct, two-way communication - a defining feature of effective parental involvement (Cary, 2006; Henderson \& Mapp, 2002; Murphy, 2013). Smart and strategic appropriation of new ICTs can strengthen communication, external outreach, and parental engagement (Carr, 2012). However, understanding what types of communication tools work best to build, maintain and strengthen school-home communication remains a challenge. Communication channels range from the mass media to interpersonal communication and interactions (Rogers, 2003). Newsletters, handouts, emails, press releases, web sites, neighborhood forums, phone calls, listservs, potluck suppers, and meetings are only some of the great variety of methods that may be successfully used to get information to and from parents. Yet ICTs chosen by administrators might not align with parent preferences and needs (Carr, 2012). Moreover, because no single method is likely to be appropriate for every parent, the use of multiple ICTs may be necessary to ensure the greatest possible efficacy. Therefore, understanding parent and principal differences and preferences when developing and deploying strategic communication plans represents a key leadership and management function for educational leaders today (Carey, 2006).

It is well understood in extant research that communication strengthens the school-home connection (Askar, 2013; Cary, 2006; Henderson \& Mapp, 2002). School-family communication plays an essential role in education success, and schools that fail to communicate effectively put students at risk. Increased and meaningful communication between home and school enhances parental involvement by inviting parents to participate in specific ways, keeping them informed, and creating a more open and collaborative school culture (Cary, 2006; Flessa, 2008; Wiseman, 2010). Technology plays an essential role in fostering communication behavior and effectiveness due to its ease of use and timely nature (Carr, 2006; Chaboudy \& Jameson, 2001). Principals and parents can use cell phones, emails, texts, mass notification systems (MNS), and other ICTs to communicate quickly with each other on topics ranging from a reminder about an upcoming school play to an emergency lockdown caused by police action in the neighborhood (Carr, 2006; Carr, 2012; Chaboudy \& Jameson, 2001). The use of technology also has the potential to increase the frequency and timeliness of communication between home and school, which helps build trust and maintain parent satisfaction with the school and school personnel. When parents trust school personnel, and feel school personnel have their children's best interests at heart, they are more likely to respond favorably to invitations to family literacy nights, take advantage of online resources offered to parents by the school, or listen to educator suggestions for ways they can support their children's learning at home (Flessa, 2008; Murphy, 2013). When parents and extended family members support learning at home and at school, student outcomes improve (Cary, 2006; Henderson \& Mapp, 2002). 


\section{Research Objective}

Currently, schools use various forms of technology to increase school-home communication, including MNS (which can contact parents at multiple locations in different languages via phone, text, and email), voice mail, e-mail, electronic newsletters and e-mail marketing, social media outreach, video conferencing, video streaming, school and classroom websites, among other platforms. In many school districts, parents also have password protected web access to individual student information such as attendance, grades, homework assignments, school events, and other news and information. However, use of these technologies is not consistent or widespread. Little research exists to inform practitioner or academic understanding regarding the extent to which technologies used by administrators to communicate with parents matches the needs, habits, and expectations of the parents. The purpose of this study is to gain a deeper understanding regarding the impact of new ICTs on school-to-home and home-to-school communication. In particular, we are interested in answering the following research questions: (1) Are principal-parent expectations regarding ICT co-aligned? and (2) Are new ICTs perceived to be changing, improving, or inhibiting administrator/parent communications? We address these questions by investigating the ICT use and preferences of parents and principals from three socioeconomically diverse public elementary schools purposely selected to provide a generous and representative variety of parent participants' socioeconomic, cultural, ethnic, racial, and educational backgrounds. Based on matched parent/principal interviews, we develop an empirically-informed understanding of the impact of new ICT's on school-to-home and home-to-school communication.

\section{Literature Review}

The foundational assumptions underlying this study are that parental involvement is correlated strongly with student achievement, and that effective communication across a principal/parent dyad fosters greater communication efficacy and improves parental involvement. The efficacy of this communication is seminal to the creation of trust, shared understanding, and a common vision regarding student expectations, achievement, and outcomes (Bryk \& Sclmeider, 2002; Cary, 2006; Henderson \& Mapp, 2002; Noonan, Walker, \& Kutsyuruba, 2008). Increasingly, new technologies play an important role in facilitating communication across this dyad. However, techno-

logical heterogeneity among principals and parents might also inhibit effective communication. It is often the case that early adopters of a technology might have more years of formal education, greater literacy, higher social status, greater financial resources, a higher degree of upward mobility, or be part of a larger organization (i.e. a school or business) (Rogers, 2003). Technology disequilibrium tends to widen the socioeconomic gaps in social systems. The diversity of students and families served by public schools today, particularly in urban settings, and the tendency of technology to widen educational and socioeconomic gaps greatly elevates the importance of understanding the role of technology in facilitating or inhibiting effective communication between principals and parents. For this reason we have chosen the diffusion process and two-way symmetrical communications theory as the appropriate theoretical lens through which to study this phenomenon. We begin with a discussion of the role of parental involvement in relevant literature.

\section{Parental Involvement}

The importance of parental involvement has been repeatedly highlighted by research and acknowledged in practice. "Parental involvement can be conceptualized as the means by which parents support their children's education and development to ultimately provide a positive influence on their academic achievement and school adjustment" (Hayes, 2011, p. 154). Parental involvement may take many forms including involvement in their child's learning at home, in the 
life of the school as a volunteer or participant in activities, and in parent-teacher organizations (Hayes, 2011; Wiseman, 2010).

Machen et al. (2005) argue that parent involvement is crucial to children's self-esteem and selfconfidence. Driessen et al. (2005) find parental involvement has two distinct forms: involvement initiated by the school, and parent-initiated involvement. They synthesize prior research to find a positive impact of parent-initiated involvement on students' cognitive and social development. Consequent to their involvement, parents develop positive attitudes towards schools which create an inviting learning environment to link with the surrounding community (Askar, 2013; Machen et al., 2005). Gonzalez-DeHass, Willems, and Doan Holbein (2005) indicate the positive consequences of parental involvement on student learning. Similarly, Shirvani (2007) demonstrates a positive correlation between parental involvement and students' academic achievement. Parental involvement can be viewed from a variety of research perspectives (Wiseman, 2010). However, the commonality among studies that consider the role of parental involvement is a strong correlation between parental involvement and positive outcomes for students, families, and schools (Askar, 2013; Cary, 2006; Henderson \& Mapp, 2002; Murphy, 2013).

Parental involvement is an important influence on child development for children of all ages (Wiseman, 2010), and can be a strong determinant of students' school performance (De Gaetano, 2007; Wiseman, 2010). Parental interaction and communication, such as participation in school functions, meetings, and activities helps foster an environment at home and at school in which parental engagement and the learning process are viewed as an investment in a child's future (Hill et al., 2004). Ongoing and supportive family involvement in children's learning at home and at school can lessen many educational challenges (Wiseman, 2010), increasing students' academic achievement (Cary, 2006; Henderson \& Mapp, 2002) and promoting positive student attitudes and behaviors (Henderson \& Mapp, 2002; Jeynes, 2007). Further, a study by the Department of Education and Skills (2003) on the impact of parental involvement on students' education finds that family participation significantly affects students' cognitive development, literacy, and numeracy skills. Other research supports the positive impact of increased parental involvement on student attendance and students' positive feelings of self (De Gaetano, 2007).

These findings are consistent regardless of parents' demographic differences and economic, racial, educational, or cultural background (Chaboudy \& Jameson, 2001). Jeynes (2007), in a metaanalysis that examines the influence of parental involvement on the educational outcomes of urban secondary students, finds that positive effects of parental involvement hold true for both white and minority students, concluding that better parental involvement may help reduce the achievement gap between whites and other racial minority groups. Increased parental involvement also improves the school environment, climate, and culture - important considerations in the school reform literature (Hayes, 2011). Moreover, family involvement facilitates connectedness between students and their parents regarding school, and enhances their interactions at home. Family involvement also improves parental mentoring regarding educational experiences, shared goals, and student achievement (Wiseman, 2010). Schools recognize the value of familial involvement in improving student outcomes, and are eager to get families more actively engaged at school and at home to support the learning process (Cary, 2006; Henderson \& Mapp, 2002). Educators who welcome parents into the school, honor their participation and connect with parents through a shared focus on their children tend to have higher levels of parental involvement and engagement across all demographic groups, "dispelling the myth that parents of different ethnic or socioeconomic background do not care" (Henderson \& Mapp, 2002, p. 1). 


\section{School-Home Communication}

Communication plays a pivotal role in encouraging and engaging parents in the learning process, both at school and at home. Frequent communication with parents helps reinforce and strengthen student learning at home, fosters greater parental interest and engagement in school activities, fuels more positive student attitudes about school and learning, and raises parents' educational expectations and aspirations for their children (Joshi, Eberly, \& Konzal, 2005). Though often overlooked, or neglected by school personnel, open, clear, welcoming and effective communication can serve as the relational glue that helps bind parents, teachers, principals and support staff together in pursuit of shared goals and high expectations for all children (Grant, 2011; Joshi et al., 2005; Thompson \& Raikes, 2007). When nurtured and sustained over time, communication builds trust between school personnel and parents, and fosters a climate of mutual respect and reciprocity that helps both parties work through any concerns, disagreements, or conflicts in a productive and beneficial manner (Thompson et al., 2007). Research has consistently shown that school practices such as frequent interaction, collaboration and communication with parents are the strongest predictors of elementary and secondary school parental involvement in supporting their children's learning outcomes at school and at home (Hayes, 2011).

While extant literature clearly supports the value of treating parents as partners in the learning process, rather than as impediments that need to be overcome, educators are often slow to embrace the reciprocity such a partnership requires (Hayes, 2011). Strong school leadership is a critical factor in parental engagement and involvement (Flessa, 2008). Principals that support and model open, honest communication and embrace parents as partners tend to have more engaged and enthusiastic parents serving in volunteer roles at school, attending school activities, and participating in parent-teacher conferences. These principals also tend to have greater parental support at home as evidenced by student attitudes toward school, homework completion, student attendance, and other measures. Principals also shape the perceptions of teachers and staff toward parents. If principals attribute students' unsatisfactory academic results, or behavior to poor parenting, teachers and other school personnel are likely to make similar attributions. As Flessa (2008, p. 18) noted, "principals tend to rely on the deficit model - what parents are not doing rather than looking at what means are in place to encourage parents to be more involved in schools". As a result, parents may feel that their contributions are devalued by educators, especially when those contributions occur at home and in the community rather than at school, and are thus "hidden" from view. As Joshi et al. (2005, p. 12) note, "For communication between parents and teachers to be meaningful and responsive, it is necessary to understand the cultural frameworks within which parents' function, since parental attitudes are influenced by cultural and economic factors".

Parents, especially those who may have had negative school-related experiences themselves, quickly perceive any negative, or condescending attitudes displayed by staff and will likely react accordingly (Hayes, 2011; Joshi et al., 2005). In addition to positive staff attitudes toward parents and parental involvement and a respectful and inclusive school climate, parents desire information from their children's schools that is clear and concise, and will help them coordinate their children's homework and other learning activities efficiently and effectively (Carr, 2006, 2010; Flessa, 2008; Joshi et al., 2005). As stated by Stalker et al. (2011, p. 242) "A key element in overcoming many potential [parental involvement] barriers lay in communicating with parents in an accessible, consistent, and informal manner". Parents also desire communication from school personnel that demonstrates care for their children and that fosters greater understanding between the parents and school (deFur, 2012). Both the quantity and quality of information families receive is important (deFur, 2012). Parents desire jargon-free communication that is culturally aware, competent, and sensitive in ways that go beyond a brief acknowledgement of holidays, a Black History month celebration, or an international food festival (Joshi et al., 2005). They also value infor- 
mal opportunities to interact with principals and teachers, and other forms of two-way communication, in which educators listen to and incorporate parents' feedback into classroom, school, and district practices and decisions (Joshi et al., 2005). As Joshi et al. (2005, p.14) note, "Researchers tell us that two-way communication is essential for building mutual trust and respect between parents and teachers; that two-way communication invites parents to tell teachers what they know about their children, their community, and their culture".

\section{Two-way Symmetrical Communications}

The importance of two-way, interactive, or dialogic communication is a recurring theme in public relations theory (Cary, 2006; Kent \& Taylor, 2002). Considered a best practice and hallmark of communications excellence, the ideal form of two-way communication is symmetrical in that both parties are willing to adapt based on collaboration and cooperation, and are committed to maintaining an ongoing relationship with each other (Cary, 2006; Grunig \& Grunig, 1992). Such two-way communications may be interpersonal, such as an individual or small group meeting, or mediated through another medium with a dialogic function, such as email, social media networks, website feedback loops, online surveys, interactive voice response systems, and other ICTs (Carr, 2006; Carr, 2012; Chaboudy \& Jameson, 2001; Grunig \& Grunig, 1992).

Unlike information dissemination, which simply broadcasts, or distributes information through the mass media, organizational publications, websites, and collateral (print) materials, two-way communications are designed to establish a dialogue between the organization and its public; in this case, the school (principals) and the home (parents) (Carey, 2006; Carr, 2010; Grunig \& Grunig, 1992; Kent \& Taylor, 2002). The goal of this dialogue is a mutually beneficial, collaborative, and satisfying relationship, one in which meaningful messages are exchanged, and the input of the public most affected by the organization are sought after and valued in the organization's decision-making processes (Grunig \& Grunig, 1992). "Symmetrical two-way public relations are more likely to lead to balanced communication effects than the other models, because constant, meaningful feedback is incorporated as an enduring component of the system" (Huang, 2004, p. 12). In addition to providing ongoing feedback mechanisms, two-way public relations uses online parent surveys, focus groups, telephone surveys, in-depth interviews, parent advisory councils, and other research strategies to gather and analyze data on parent concerns, preferences and needs regarding communications, the school's academic program, after-school enrichment activities, and other topics (Huang, 2004). This data is then used to inform the school or district communications program in much the same way that student achievement data (both formative and assessment) is used to modify, adapt, and improve the school's instructional program. As Kent and Taylor (2002, p. 26) note "when an organization is fully engaged in its community (local or global) it will have broader contexts and wider perspectives to draw upon in its decision-making. Engagement benefits all parties involved because decisions serve multiple publics".

\section{Diffusion of Innovation}

Symmetrical communication is to some degree reliant on convergent ICT use across stakeholders engaged in communicating. However, diffusion of technological innovations across social systems is typically not even and homogenous (Rogers, 2003). Some people rush to buy the latest technology, while others wait until it is nearly obsolete. Meanwhile, near constant innovation of ICT during the last few decades has given us the Internet, cell phones, emails, text messages, tweets, streaming video, etc. ICT innovations continue to dramatically alter the devices, channels, and strategies by which we communicate with one another (Rogers, 2003). Constant innovation and variant rates of technology diffusion might result in a heavily fragmented communications landscape in which multiplicity rather than ubiquity is the norm. 
Diffusion of innovation theory is concerned with how innovations spread across social systems over time (Rogers, 2003). In public relations practice, diffusion theory is used to help map out strategies tied to persuading different audiences, or groups - such as parents or principals - to consider new ideas, adopt different perceptions, take specific actions, and adopt new behaviors, such as principals communicating regularly with parents, or parents attending school functions more frequently (Grunig \& Grunig, 1992). Within this context, diffusion theory indicates that mass communication and one-way techniques work well during the initial stages of interest and awareness, while more personalized, interactive, and two-way techniques and hands-on experiences are required during the latter stages, particularly if individuals or groups are going to move from awareness to evaluation, trial and adoption (Grunig \& Grunig, 1992; Rogers, 2003). (See graphic illustration of diffusion process with symmetrical communication theory overlay in Figure 1.)

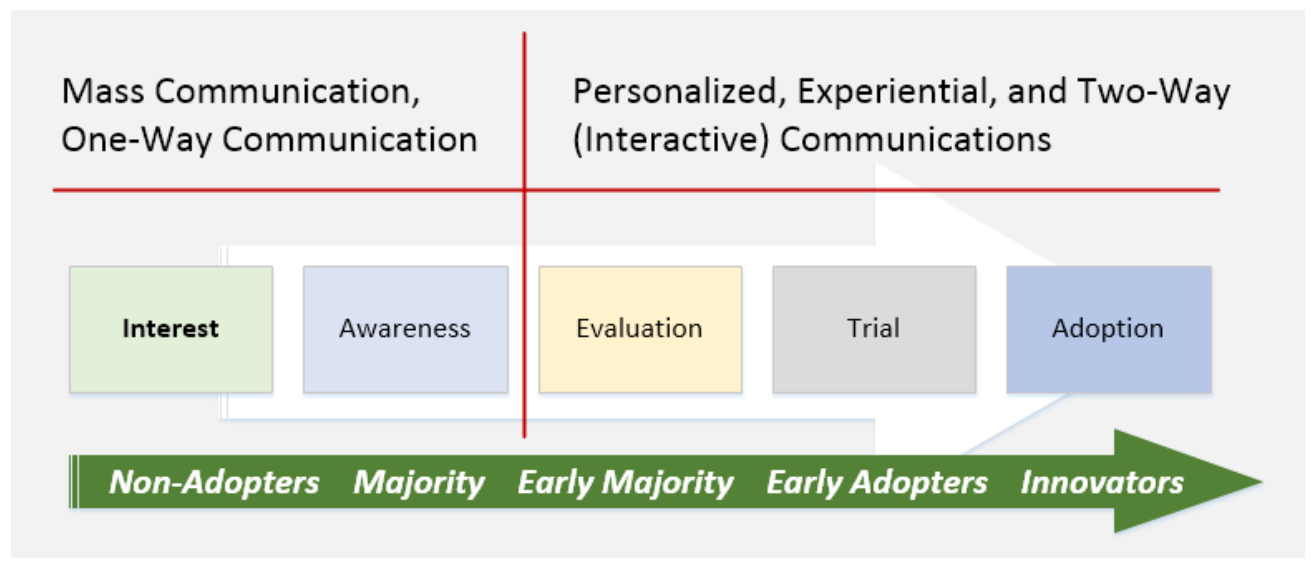

Figure 1: Diffusion process/theory with symmetrical communications theory overlay (adapted from Grunig and Grunig (1992), Rogers (2003), and Singhal and Rogers (2001))

Although Rogers' definition is broader, innovation herein refers specifically to ICT innovation. Rogers (2003) theorizes that individuals adopting an innovation can be categorized as innovators, early adopters, early majority, late majority, and laggards. The decision regarding whether to adopt an innovation is shaped by characteristics of the technology and of the adopter. However, the focus of this study is not on the characteristics of the technology, but those of the adopters. Prior studies have demonstrated that early adopters of an innovation can be characterized as better educated, more likely to be literate, of higher social status, and possessing greater financial resources and upward mobility than the other groups (Rogers, 2003). Similarly, early adopters can be ascribed different communications behaviors. Early adopters are commonly more highly interconnected, having a higher degree of exposure to interpersonal communications channels, and more actively engaged in information seeking behaviors (Rogers, 2003). In addition to socioeconomic considerations, the contrast between early and late adopters also is described along dimensions of personality and communicative style, as well as access to mass communication channels, social norms and cultural preferences (De Gaetano, 2007; Hayes, 2011; Louis \& Whalstrom, 2011; Rogers, 2003). In this research, we seek to understand the similarities and dissimilarities in ICT adoption between principal/parent dyads along the following dimensions: (1) socioeconomic self-characterizations; (2) ICT availabilities; (3) individual ICT adoption characteristics; and (4) primary individual preferences of ICT. In understanding convergence and divergence along these dimensions, we hope to better understand ICT alignment across the principal/parent dyad and the impact of its symmetry on shared perceptions of communication efficacy (see Figure 1). Accordingly, we developed our research framework, shown in Figure 2, of Principal-Parent ICT Convergence and Divergence. 


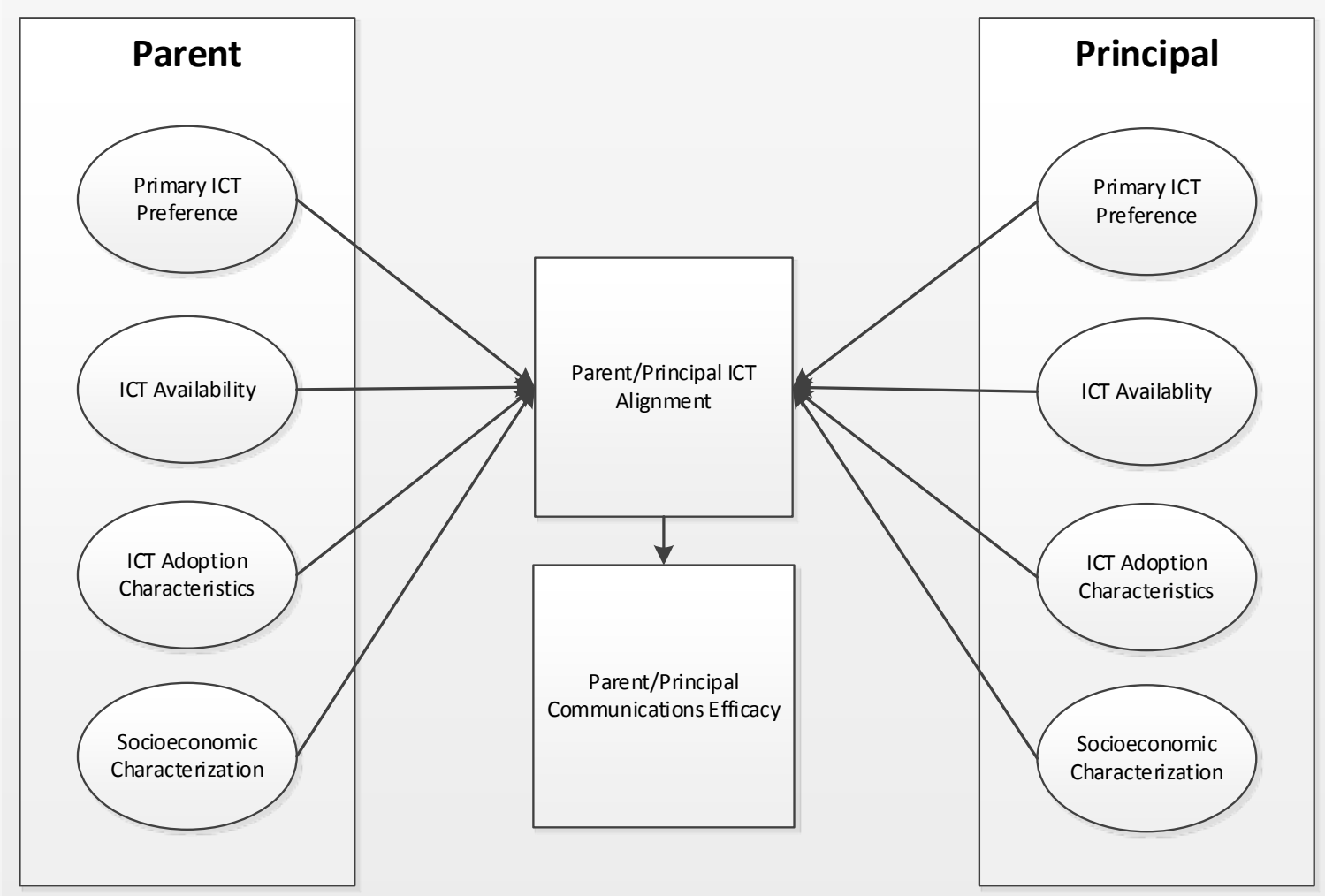

Figure 2: Research framework of parent-principal ICT convergence and divergence

\section{Methodology}

According to Creswell (1998, p. 18), qualitative research is "an inquiry process of understanding based on distinct methodological traditions of inquiry that explore a social or human problem". Qualitative analysis relies on methods such as interviews, observation of individuals, and controlled subjectivity to build an understanding of the meaning of events, situations, or actions as reflected by participants in the study. The qualitative approach can generate rich and detailed data suitable for triangulation and verification across multiple data points and perspectives, providing deeper insight into reported and observed phenomena (Creswell, 1998). We employ qualitative methods in this research to conduct a multi-case investigation of the research questions which motivate our work: (1) Are principal-parent expectations regarding ICT co-aligned? and (2) is convergence/divergence in the adoption of new/advanced ICTs perceived to be changing, improving, or inhibiting administrator/parent communications? By studying a small number of cases and at the same time preserving the individuality of each case, this form of qualitative analysis affords deep understanding of the phenomenon of interest - the impact of new ICT on schoolhome communications.

\section{Data Collection}

Parent/principal interviewees were selected from three public elementary schools in populous Hartford County, North Carolina (fictional name used to assure anonymity). Schools targeted included an urban magnet/choice school with a diverse student population of mixed wealth/socioeconomic status, a high wealth suburban/high wealth school with a majority white student population, and an urban/low wealth school with a minority-majority student population, including a high percentage of recent immigrants. The three schools were selected to provide a generous and representative variety of parent participants' socioeconomic, cultural, ethnic, racial, 
and educational backgrounds. Once the schools were identified and selected, principals were contacted to enlist their support and participation in the study. Once principal interviewees had been identified, they were engaged in helping the researchers identify a diverse group of parents ( 5 to 8) from each school, including those visibly active at school and those who are not.

With the permission and assistance of the principal and classroom teacher, notes were sent home via potential parent interviewees' children to explain the purpose of the study, the length of time required, and to request interview and contact information. Parents then contacted the researcher(s) and/or the school to indicate their interest in participating. The researchers then contacted the parents via a phone call or email, depending on their stated preference. Parents who agreed to sit for an interview were provided a consent form prior to their participation. Particular attention was paid to explaining what is meant by ICTs by way of a list of devices from which they could make selections. ICT adoption terminology was described in terms of their interest in buying and using the latest communications gadgetry, and by probing for actual ICT use via a structured interview protocol (see Appendix).

Data was collected during interviews from three principals and eleven parents (spread evenly across schools), including one male-female couple who preferred to be interviewed together. Parents were given their choice of location and time for the interviews, with the majority choosing to participate at their child's school. Two parent interviews were conducted at one of the researcher's offices, two at restaurants near their children's schools, and one parent interview was conducted via the phone. Data also was collected from multiple documents and sources, including school websites, sample school communications (if available), U.S. Census Bureau (2012), Parent Opinion Polls, and so forth. All study participants were interviewed once. The interview length averaged between 30-60 minutes and was conducted in a semi-structured conversational approach and consists of structured questions as well as ad-hoc follow-up and probing questions (see Appendix). All interviews were recorded with the interviewee's consent. In some cases, the interviewees asked the researcher to turn off the recorder and/or computer, but allowed the researcher to continue recording data with hand-written notes. Following the interviews, each interview session was transcribed verbatim and shared among researchers for coding.

\section{Data Analysis}

Data analysis involved identification of themes within individual cases as well as across cases and individual interviews. Descriptions, researcher discussions, and a coding scheme were applied to the interviews by each researcher and used to identify: the kind of ICT currently used by schools and parents; ICT habits and preferences of principals and parents; and parental expectations regarding ICT school communications. Interviews were then coded and mapped out by research question. The case study method has allowed for a detailed view of the convergence and divergence of these actors around the research questions developed in the study. Though guided by theory and a conceptual framework, categorical aggregation was used to allow insight to emerge from the themes found in the data. Themes were identified from the interviews by highlighting key concepts and ideas. Concepts and ideas were sorted into groups based on their similarity. A similar process was used to code and sort the information obtained from supporting documents. Themes identified by individual researchers were then analyzed and vetted by the research team, and findings were culled to distill the data deemed most relevant to the purpose of the study, the study's theoretical and conceptual framework, and the original research questions. Lastly, these themes were organized and combined into categories used to form insights to guide the research outcome. 


\section{Researcher Subjectivity}

Researchers should be attentive to their subjectivity as it may influence the objectivity in collecting, understanding, analyzing, and reporting the outcomes of the study (Creswell, 1998). Therefore, monitoring of one's self and being aware of how past experiences may influence researcher perceptions and interpretations is vitally important (Creswell, 1998). In this study, the researchers relied upon open-ended questions, with researchers volunteering no judgment, commentary, or opinion, although empathy and other emotional and verbal cues of encouragement were used to develop rapport with the interview subjects and maintain the conversation/dialogue flow. To address bias and assure inter-coder reliability, interviews were coded by multiple researchers. Researchers purposefully raised alternative explanations and interpretation of the interviews, and questioned each other's assumptions and interpretations. Researcher subjectivity was monitored through recording and transcription of full interviews, where possible, given some parent subjects' hesitancy in being recorded. Two of the researchers are information systems specialists, while the third is a high-ranking employee of a school system, similar to the one where the study took place. In order to keep this researcher's position from influencing study participant response, and to alleviate any concerns participants might have that study results would be used as part of any personnel or school evaluations, the team decided to have one of the information systems researchers conduct the principal interviews. Further adjustments to the process were made when it became clear that parents were unsatisfied at one school. Rather than make the principal feel uncomfortable, and/or risk allowing the study to be used for non-research purposes (such as sending a message to central office administrators) by dissatisfied parents, the information systems researchers conducted these interviews as well. In this manner, the research team worked to remain objective, as much as possible, as they were gathering, analyzing, and interpreting the data.

\section{Trustworthiness}

Trustworthiness was verified through triangulation of the findings from multiple data sources and member checking. According to Guion, Diehl, and McDonald (2011, p. 29), "Triangulation is a method used by qualitative researchers to check and establish validity in their studies and includes data triangulation, investigator triangulation, theory triangulation, methodological triangulation, and environmental triangulation". Using multiple and different sources of data helps to ensure the accuracy of data and strengthen the study outcomes. Uncovering the same information from more than one case can help to describe how findings occurred under different circumstances and assist to confirm the validity of the findings. Moreover, investigator triangulation helps to ensure completeness of the findings. All of the investigators discussed their findings with one another and reached consensus on conclusions which are inclusive and reflective of all evidence collected.

\section{Results}

In the section that follows, we describe the socioeconomic and ICT adoption characteristics and preferences of the three parent-principal pairings revealed through our investigation to inform the research questions that motivate this study: (1) Are principal-parent expectations regarding ICT co-aligned? and (2) is convergence/divergence in the adoption of new ICTs perceived to be changing, improving, or inhibiting administrator/parent communications?

\section{ICT at the Low-Wealth Urban School}

The principal at the low-wealth urban school considers herself and her staff early adopters of ICTs, although our research team unanimously places her in the late majority category. She holds this self-perception based on the relative sophistication of her ICT use compared to the parents with whom she communicates. 
I think that we're probably closer to early adopters than not. Although our resources may be limited, we have taken advantage of opportunities to try to put things out there for our parents. We're constantly looking for ways to better our communication and make it more appealing to parents and more user-friendly to them. We might not be the cutting edge school, but we're always open to new ways. (Urban School Principal, 2012, lines 102-106)

Many of the parents at this school face economic and cultural barriers, including limited English proficiency. Located within a longtime refugee resettlement community, the school serves a large number of immigrant families and has students who come from 22 countries and speak more than 12 different languages. In order to communicate with parents effectively, the principal typically sends messages and information to parents in at least three languages: English, Vietnamese, and Spanish (see Table 1).

Table 1: Ethnic diversity of urban school students

\begin{tabular}{|l|l|}
\hline \multicolumn{2}{|l|}{ Student Population } \\
\hline African-American & $49.4 \%$ \\
\hline Asian & $21.8 \%$ \\
\hline Hispanic/Latino & $17.7 \%$ \\
\hline Multi-racial & $6.2 \%$ \\
\hline Caucasian & $3.8 \%$ \\
\hline American Indian & $1 \%$ \\
\hline
\end{tabular}

Recently arrived Montagnard immigrants comprise one of the largest ethnic groups at the school, adding their own unique traditions and cultural mores to the school, which works hard to create a welcoming and inclusive climate and culture (Urban Principal, 2012).

Approximately 81 percent of the students at the urban low-wealth school qualify for free or reduced lunch (FRL) (Hartford County Schools, 2012). The FRL is a federal measure of the poverty level of the population served by the school. The socioeconomic mix includes some parents who are highly educated and employed in professional positions, but numerous others who are living on some form of local, state, and federal assistance or disability. A significant portion of the school's parents do not have a high school diploma and qualify as working poor, often employed in one or more part-time or fulltime low-wage positions (see Table 2).

A recent report by the Pew Research Center's Internet and American Life Project finds Internet use in the U.S. is strongly correlated with age, ethnicity, education and household income (Zickurh, 2013). Certain demographic groups are far less likely to have Internet access than others. Among these are non-native English speakers (24\% lack access), adults without a high school education (41\%), and households earning less than $\$ 30,000$ per year $(24 \%)$. Each of these demographic groups is well-represented in the population served by the urban low-wealth school. 
Table 2: ICT characteristics of parents and principals - low-wealth urban school

\begin{tabular}{|c|c|c|}
\hline Urban School & Parents & Principal (or School) \\
\hline $\begin{array}{c}\text { Primary ICT } \\
\text { Preference }\end{array}$ & $\begin{array}{l}\text { MNS } *=\text { school news/activities } \\
\text { Email = personal communication } \\
\text { Voice = personal communication } \\
\text { Text msg. = personal communication } \\
* \text { Mass notification system (MNS) }\end{array}$ & $\begin{array}{l}\text { MNS = school news/activities } \\
\text { Email = personal communications } \\
\text { School website = school } \\
\text { news/activities } \\
\text { Teachers' websites = class activities } \\
\text { Voice calls = personal } \\
\text { Parent Assistant = personal }\end{array}$ \\
\hline ICT Available & $\begin{array}{l}\text { MNS } \\
\text { Email } \\
\text { Text msg. } \\
\text { School website ** } \\
\text { Teachers' websites ** } \\
\text { Voice calls } \\
\text { Social Media } \\
\text { Electronic newsletters } \\
\text { Parent Assistant web portal ** } \\
* * \text { many lack Internet access }\end{array}$ & $\begin{array}{l}\text { MNS } \\
\text { Email } \\
\text { Text msg. } \\
\text { School website } \\
\text { Teachers' websites } \\
\text { Voice calls } \\
\text { Social Media } \\
\text { Electronic newsletters } \\
\text { Parent Assistant web portal }\end{array}$ \\
\hline $\begin{array}{l}\text { ICT Adoption } \\
\text { Characteristics }\end{array}$ & Late Majority/Laggards & Late Majority \\
\hline $\begin{array}{c}\text { Socioeconomic } \\
\text { Status }\end{array}$ & $81 \%$ free or reduced lunch & Low-Wealth Urban School \\
\hline
\end{tabular}

Many of the parents interviewed lack access to computers or the Internet from home.

We go to the library every week. My daughter can get on a computer at the library to do her homework, read books, play games. (Urban School Parent 3, 2012, lines 206-207)

I'd be lying to you to say more than half of the parents I know have computers. (Urban School Parent 1, 2012, lines 260)

I don't have a computer at home. I do have an email address, and I have email access at work. [Parent noted she currently works part-time but would like to find something fulltime.] I have a cell phone. I just got one. I don't have a [land line] phone. (Urban School Parent 4, 2012, lines 46-49)

The urban school principal works actively to identify resources to help parents acquire refurbished computers at low or no cost. She believes there is a direct link between access to computers and the Internet in the home and parental engagement.

Usually the parents I don't see are the ones that don't have [Internet] access. My parents that are active and in communication with the teachers, they're the ones that have something to communicate with. They kind of go hand in hand. Rarely am I going to find a parent who we never see and never talked to who is checking everything on the Internet. (Urban School Principal, 2012, lines 160-164) 
At the low-wealth urban school, the principal and other staff regularly tutor parents on how to use technology, including the Internet and email, to check their children's grades, search for jobs and housing options, and find out about community resources. The school hosts free Saturday classes to help parents earn their General Equivalency Degrees (high school diplomas) and learn Spanish or English. They host sessions in their computer lab to teach parents to access websites and educational resources at home. They put technology in their hands to help connect them to the things going on at school.

We have tried to keep it simple, and present things in a simple way that is easy to understand. We've done technology workshops here and there. We try and teach $21^{\text {st }}$ century skills and expectations for our children, and we want our parents to support them. But, they have to have the same support and skills as well. We want our students to be globally aware learners. Parents are not going to understand how technology is the connector for us, particularly if they've not utilized it themselves. (Urban School Principal, 2012, lines 168-171)

The urban school principal surveys parents to gauge their communication preferences, and then tailors her communication to meet their needs. She uses an extensive and impressive mix of ICTs, traditional, and non-traditional communication methods to inform and engage parents, targeting a fourth grade reading level (Urban School Principal, 2012, line 324). These methods include, but are not limited to: the district's MNS, email, school and teacher websites, text messages, fliers, posters, the school marquee, the carpool line, school-wide announcements, notes sent home with students, special family events, student performances, phone calls, personal outreach, and an open invitation to parents to eat lunch with their children in the school's "restaurant" area, which features smaller tables, table cloths, special lighting, and other amenities set-up on the stage in the school's multipurpose room, which also doubles as its cafeteria.

The school also served as a pilot site for the district's relatively new Parent Assistant program, which provides parents with online access to their children's grades, attendance, standardized test scores, and homework assignments.

It's called Parent Assist. We were one of the first elementary schools to pilot this online system which gives parents quick access to their children's attendance $K-$ 5. If they're third, fourth, or fifth grade they can also access their grades...the teacher grade-book. And they can also pull their report card. We have steadily and slowly convinced parents to use this tool, but not to the degree that we'd like. I think we're up to about $14 \%$ all of our population that's using it. We were stuck at $3 \%$ at one point so we're really encouraging parents. And we've seen over the year that it's picked up slightly. One of the things that impacts usage a little bit is that there is a rigorous background check and application process to give parents access, because we have to be certain of parental custody issues. It's designed so that it's secure. It takes a few days to get in. There can't be any incorrect characters, or that type of thing, so I think that's a little bit of a deterrent. It needs to be secure, because you're able to access all of your child's information. But I think that's something parents have to get used to. (Urban School Principal, 2012, lines 173-179)

The school actively maintains a website intended to communicate general information about school news, events and activities to parents. In addition, teachers maintain subpages within the site to share information specific to their class and classroom activities.

We post school and Connect-Ed messages on our website, and they (parents) can go on at any time and replay the message. It's an mp3 clip. They can listen to it 
any time. And we also print it on the website. We have Babelfish there so they can translate it. It is very cool. I like Babelfish. (Urban School Principal, 2012, lines 55-57)

While the school site is regularly updated, the classroom-specific subpages maintained by the teachers are not.

They aren't updated as regularly as they should be. Honestly, we've had so many areas of focus this year that I did make sure everyone had one set up, but we're not monitoring it as frequently this year as I'd like to. That is on our list, to help continue to support teachers with. If I said [to a parent] go to your teachers website to look at XYZ they would do it. But because I know they're not as developed or as current as they need to be, we don't send them that way. We'll send them to the home page... and they can pull information from there. And that stays updated. (Urban School Principal, 2012, lines 62-68)

Parent surveys at the urban school indicate that the MNS, which uses voice mail broadcasting, represents parents' preferred communication channel for news and events at the school (Urban School Principal, 2012, lines 68-69). One parent described communication as follows:

We get a Connect Ed (name of MNS) every 6 p.m. Sunday night like clockwork. She sends fliers home to remind you. These say, "Come to school and see fliers up on the hall." Like I said, her communication is basically awesome to me. I also get email. We [parents] don't get texts. We only get those from the school administration. The primary ways of communication are written, email, or Connect-Ed. We also have Parent Assist. They (the teachers) don't do it just for classroom grades. But, I don't use that part much. When I want to know something I just stop by the classroom and see the grades. The teacher emails me an update every Thursday. (Urban School Parent 1, 2012, lines 206-216)

Several of the parents interviewed indicated their preference to receive text messages from the school. This appears to be linked to the higher availability of smartphones and their dependence on them, rather than computers, to communicate with others. One parent offered the following:

We don't get texts [from the school] ...I feel like we're in a texting era. A lot of parents have a cell phone, even if they don't have a computer. You have to face reality. A cell phone is totally different than a computer. A lot of them text. I hate to say there are parents out there that don't check their child's book bag or that toss a flier and don't read it. So, a text would make it seem more personal. It's a powerful tool [texting]. (Urban School Parent 3, 2012, lines 88-93)

This points to a gap between the ICT preference of the parents and the principal. which has implication regarding communications efficacy. However, this gap is not a consequence of a mismatch in ICT availability. Regarding text messaging, the principal offered the following:

There is actually an option [on MNS] where you can text the message or email the message. I've not exercised it yet but I'm planning to exercise it very soon. I think parents would appreciate that. That's what I need to understand a little better. If it's the home message that I send, sometimes that can be a little lengthy, and I don't want to... You know people might have a certain amount of minutes [on their phone plan] and I don't want to impact that. But for parents who would like to have the home message texted to them that would be a nice option. (Urban School Principal, 2012, lines 88-93) 
It is important to note that the school district does use text messaging to broadcast emergency communications to parents based on the contact information provided at the time of student registration.

The low-income urban school represents a challenging communicative environment with high variability in the ICT available to parents and in their skills to use them. The principal and her staff rely on a number of Internet-based ICTs to share information and communicate with parents. These are provided and supported by the local school district. However, a significant percentage of parents at this school do not use or have access to computers or the Internet. Ongoing efforts by the principal to teach Internet skills to parents and assist them in acquiring refurbished computers highlights her belief that better ICT alignment is needed. Low adoption rates for Parent Assist bear out the challenge the principal faces in communicating with parents via Internet-based ICTs. Interviewees provide anecdotal evidence that many parents would prefer the school communicate with them using text messaging. Demographic data on Internet use in the U.S. supports the notion that text messaging would be a more effective way to reach many of the parents at this school (Zickurh, 2013) who do not use the Internet. However, the principal has not yet embraced text messaging as a means of communicating with the parents for whom texting is their primary ICT of choice. This suggests misalignment in the ICT preferences of the principal and some parents. Interviewees, including the principal, support the view that better ICT alignment would increase communications efficacy.

\section{ICT at the Urban Magnet/Choice School}

The principal at the science and technology magnet school considers himself and his staff early adopters of ICT. He uses a robust array of ICTs to communicate with parents, including Skype and Facetime (web-enabled voice/video services), digital video, digital photography, and podcasting, as well as a number of high-tech devices, including iPhones, iPads, and iTouches along with laptops. This is in keeping with the science and technology theme of the school. The research team categorizes him as an early adopter/innovator. He and his staff are innovative in their use of ICT to facilitate communication and engagement with parents and students.

One of the things I've started doing is the Apple equivalent of Skype - called Facetime. I've started to expand on that. There are some kids that I connect with who are a discipline challenge. So the deal is, once a week...or every other week, just to Facetime with them so we can meet face-to-face and they can give me an update about what's going on with them. We use Facetime in a variety of ways. We had a teacher who wasn't going to be able to start the year because she was having a baby. So I said, okay here's an I-pad, one of the II's with a camera. As long as you have Wi-Fi at home, what I want you to do is just the first day of class, even though there is going to be a sub in the room for me the first couple of weeks, I want you to hook this up and we'll connect to a TV in the classroom, and you can give a greeting to your students. And that's your way of connecting with them at the very first day of school, even though you're physically not here. So that worked really well. That was just a cool way of saying hey kids there's your teacher. We do a lot of that around the school. (Magnet School Principal, 2012, lines 114-121)

As a magnet/choice school, students must apply to the school and are selected for enrollment via a random lottery, although siblings of current students and students who live within a designated "walk zone" near the school are given preference. Located within the city limits, the magnet school's student body represents a cross-section of the county (although it skews slightly more towards affluent and Caucasian than the district as a whole) (see Table 3). 
Table 3: Mixed-wealth urban school

\begin{tabular}{|l|l|}
\hline \multicolumn{2}{|l|}{ Student Population } \\
\hline Caucasian & $62.8 \%$ \\
\hline African-American & $26.6 \%$ \\
\hline Multi-racial & $3.9 \%$ \\
\hline Hispanic/Latino & $3.3 \%$ \\
\hline Asian & $3.3 \%$ \\
\hline
\end{tabular}

The percentage of students at the magnet school who receive free or reduced lunch is only 34.7 percent, compared to the district-wide average of 56.6 percent (Hartford County Schools, 2012). Parents of students attending the school are generally well-educated, with over a third having earned at least a bachelor's degree.

This school actively maintains a website to communicate information to parents regarding the school events, lunch menus, special programs, curriculum, classroom assignments, field trip notices, and other topics. In addition, the PTA supports a linked website with additional information for parents. All of the teachers at this school maintain subpages on the school site to communicate information to parents and students regarding the activities in their classrooms.

Teachers and other school personnel, as well as the PTA, maintain an "incredible amount of information" on the school website, which school personnel "constantly [refer] people [to] who are looking for basic information. There are links for lots of resources or further information. Each of the teachers has websites. A good number have made them functioning working websites, with information, podcasts, assignments, homework, lessons posted, information about field trips, or special events. (Magnet School Principal, 2012, lines 245-248)

Several of the parents we interviewed indicated their frequent use of the school and teacher websites and were able to provide a rich description of their content and utility.

We use our iPads at home to get all of our emails and read them, and to get information from the school's website, because they [the school] do a lot of posting there. We get information on upcoming events and things that are happening, school breaks, holidays, and news. We always go to the first grade webpage, and then to our teacher's page where we can click on links and play educational games and fun stuff that helps my son make progress. What they [the class] are working on at school and their homework is posted on there too, so if a homework paper is lost I can go on there and see their assignment. (Magnet School Parent 2, lines 96102)

Parents at the mixed-wealth urban school are generally more affluent with better access to ICT than parents at the low-income urban school (see Table 4). Most have access to computers and the Internet from home. Much of the communication between the school and parents is via email.

I took a week off to attend a conference back in December. And when I got back, I only had three voicemails on my phone. And the secretaries don't take phone messages, so everything goes to my voicemail. Instead, I had five hundred twenty three e-mails that needed some degree of response. This is something that has evolved with staff, parents and myself. Everyone knows if they send an e-mail that I will re- 
spond within 24 hours, but usually much, much sooner. Sometimes, the emails are simply someone wanting to discuss something regarding a class or a child's interaction with a teacher. I'll tell the parent 'be sure you copy me on any future correspondence and I'll be sure to tell the teacher'. That way, if the teacher is sending something to a parent and they copy me, the parent knows that I'm already in the loop. (Magnet School Principal, 2012, lines 220-229)

Table 4: ICT characteristics of parents and principals - mixed-wealth urban school

\begin{tabular}{|c|c|c|}
\hline Magnet School & Parents & Principal (or School) \\
\hline $\begin{array}{c}\text { Primary ICT } \\
\text { Preference }\end{array}$ & $\begin{array}{l}\text { MNS * = school news/activities } \\
\text { Email = personal communication } \\
\text { Voice = personal communication } \\
\text { * Mass notification system (MNS) }\end{array}$ & $\begin{array}{l}\text { MNS = school news/activities } \\
\text { Email = personal communications } \\
\text { School website = school } \\
\text { news/activities } \\
\text { Teachers' websites = class activities } \\
\text { Voice calls = personal } \\
\text { FaceTime = personal }\end{array}$ \\
\hline ICT Available & $\begin{array}{l}\text { MNS } \\
\text { Email } \\
\text { School website } \\
\text { Teachers' websites } \\
\text { Voice calls } \\
\text { Text msgs. } \\
\text { Social Media } \\
\text { Electronic newsletters } \\
\text { FaceTime } \\
\text { Skype }\end{array}$ & $\begin{array}{l}\text { MNS } \\
\text { Email } \\
\text { School website } \\
\text { Teachers' websites } \\
\text { Voice calls } \\
\text { Text msgs. } \\
\text { Social Media } \\
\text { Electronic newsletters } \\
\text { FaceTime } \\
\text { Skype }\end{array}$ \\
\hline $\begin{array}{l}\text { ICT Adoption } \\
\text { Characteristics }\end{array}$ & Early Majority & Early Adopters / Innovators \\
\hline $\begin{array}{c}\text { Socioeconomic } \\
\text { Status }\end{array}$ & $34 \%$ free or reduced lunch & Mixed-Wealth Urban School \\
\hline
\end{tabular}

The magnet school parents we interviewed were unanimous in describing email as their preferred ICT for routine communications between themselves and the school.

I really prefer email. I can get the information on the go at any time. But, the [MNS] phone calls weekly are effective if you are aware that by not answering them you have them in your voice mail. Me, in particular, I'm an on the go type of person, so I like email. (Magnet School Parent 2, lines 132-135)

Like the principal at the low-wealth urban school, the principal at the magnet/choice school believes there is a direct link between ICT access and parental engagement. He actively engages with the school's PTA to make sure as many parents as possible have access to the same technology used by their kids at school and offers training to help them use it.

So we started with the [iPad] Touches, and then moved up to the iPads. We got the PTA on board. And they really didn't necessarily understand all of it. But they trusted us enough to say OK, we'll support it. What they did was that they could go out and negotiated a little bit better deal with a third party vendor. So they set up opportunities for people to purchase devices at a small discount over what they 
could do at the Apple store because it was in volume. So we were able to get some of the technology in the hands of parents at a reduced cost. The more they understood... The more they used it, the more they understood what we were doing for the school and the more they became partners. We did some training for them, and said "just come on in", and we gave them some tips. They could see what we were doing, and how it connected to what they were seeing their children do, and then again they were more supportive. Sometimes it's like, "what is this, the latest trend?" But then they see how it fits and they become champions. (Magnet School Principal, 2012, lines 299-306)

The magnet school parents we interviewed all use text messaging to communicate informally with friends and family. However, none expressed any interest in text messaging with the principal, teachers or staff. One parent explained:

I don't have a landline at home, just my cellphone. I do a lot of texting and emails...more of that than conversations on the phone, because I am always busy and have kids around. So a lot of times it's easier for me to have conversations with friends through texts because I'm not interrupted. The school doesn't do any of that [text messaging]. But to be honest, I don't know if I would feel comfortable texting with the principal or the teachers. I just feel like that's more informal. I don't know if, for professional people, that would be the right way to communicate. I just don't think it would be helpful. Face-to-face is best for me to talk about my son. I can see the emotions of the teacher. To be honest, there isn't much I would change about the way <redacted $>$ communicates with me. I think they've done a phenomenal job. (Magnet School Parent 3, lines 144-152)

The principal at the magnet school, as a matter of policy, does not condone text messaging with parents.

There are 22 student teachers at our school. One of the student teachers just sent home an electronic newsletter which included her cellphone number, should parents wish to get in touch with her. We had a father that started coming in, being a bit flirtatious and forward. Then he sent her a couple of text messages which we believed were inappropriate - 'Gee, I really like the way your hair looked this morning', etc. It was way out of line. The senior and student teachers came in and made me aware of it.... I told him those kinds of communication had nothing to do with his son's progress in the third grade...to just stop. He stopped. That is one of the downsides of having people text. (Magnet School Principal, 2012, lines 333346)

The magnet school parents interviewed indicate high levels of satisfaction with school communications and with the principal's use of ICT. The general sentiment of the interviewees is reflected in the following comment:

I have a very good open line of communication with the school, and I think they are doing, you know, a great job with that. So, I don't think really there is a lot of room for improvement at all. I think they've got it covered pretty well. I feel like I am really in the loop as a parent. I get a Connect-Ed message every Sunday at the same time, and I get emails from the school with things I should know. My son's teacher does a great job of keeping the class website up to date so I know what is going on. (Magnet School Parent 1, lines 49-52) 
The communicative environment of the magnet/choice school is far less heterogeneous than that of the low-wealth urban school. Parents here are generally more educated and affluent, and the majority is native English-speakers. Most have access to the Internet and Internet-enabled ICT from home, and the magnet school principal and his staff rely on a number of Internet-based ICTs to share information and communicate with them. Therefore, we find a high degree of alignment in ICT availability between the parents and the school. We find a high degree of alignment regarding ICT preference as well. The principal and parents indicate email, MNS, and the school and classroom websites are their preferred ICT. While several parents report their frequent use of text messaging for communicating with family and friends, none suggested text messaging would be useful in communication between themselves and the school. Relative to the parents and students, the magnet school principal believes he and his staff are early adopters and innovators regarding their use of ICT. We, as researchers, agree with their self-assessment. They are pushing the boundaries of home/school communication with new ICTs such as FaceTime. Parents expressed a high degree of satisfaction regarding their communication with the principal and his staff and describe it as very effective.

\section{ICT at the Suburban/High Wealth School}

In contrast to the other principals who consider themselves early adopters of ICT, the principal of the suburban/high wealth school considers herself and her staff late adopters, or laggards. What is significant about this finding is that, in many ways, the principal is actually more sophisticated in her use of ICTs than the low-wealth urban school principal, and uses nearly the same complement of technology as the science and technology focused magnet school.

I would say we're late ... I'm not comparing us to other school systems per say, but just in general the educational system has not kept up with the technology that surrounds us in a fast enough pace to make teachers feel comfortable using it or to even have the capability to use it. (Suburban Principal, 2012, lines 97-107)

This principal recently led the transition of the school's newsletter from print to digital, and has helped champion the successful creation of more robust websites to share information more effectively with parents. Under the principal's guidance, the PTA and school personnel have recently begun using web services to create and send attractively formatted, colorful electronic newsletters coded in html to parents.

She (the principal) does a newsletter every week. Most of them include event dates, testing dates coming up, general news about what is going on at the schoolwhether that's party schedules, changes in traffic flow, new developments on the playground, guest speakers, etc. I know she (the principal) always sends that newsletter on Monday, so I know when it's coming, so I look for it. Recently she (the principal) made the newsletter much more creative. It's now in html. Before it was just the regular type, just black and white, and not in template form. Now it has lots of colors, and is segmented by boxes, so it's easier to find important information and it's much more interesting to read. (Suburban Parent 3, 2012, lines 125-132)

In stark contrast to the other two schools, the suburban school is much less diverse and much more affluent (see Table 5). Only 13.6 percent of students here qualify for free or reduced rate lunch (one of the lowest rates in the county), and many parents hold executive level positions (Hartford County Schools, 2012; Suburban Principal Interview, 2012). The average family income and home price in the community where the school population is situated are more than double that of the national average (U.S. Census Bureau, 2012). Approximately 47.4 percent of adults age 25 and older in this community hold a bachelor's degree or higher, as compared to the 
national average of 32.4 percent (U.S. Census Bureau, 2012). Highly educated, affluent, and technologically savvy, the parents typically have access to a variety of ICTs at home, work, and on-the-go.

Table 5: Ethnic diversity at suburban school

\begin{tabular}{|l|l|}
\hline Student Population & $85.3 \%$ \\
\hline Caucasian & $4.8 \%$ \\
\hline African-American & $4.0 \%$ \\
\hline Multi-racial & $3.3 \%$ \\
\hline Asian & $2.0 \%$ \\
\hline Hispanic/Latino & \\
\hline
\end{tabular}

The principal at the suburban school tends to rely heavily on email to communicate with parents, and uses the MNS only in cases of emergency.

We have all of our parents in an e-mail database. The quickest and most efficient way for us to communicate is to email our parents. We have a very low bounce back rate. It was a little scary thinking about doing seven hundred plus students because I just had this vision of every week one hundred e-mails bouncing back to me. Once a month we might get one or two e-mails bounce back to us... and just quick response... With e-mail every single week we send out a school-wide newsletter from my office. We also send out a weekly PTA newsletter via e-mail. Then, each teacher sends out their own individual teacher/classroom account. (Suburban Principal, 2012, lines 41-43)

However, several of the parents interviewed expressed their preference that email be used in conjunction with the MNS as their ICTs of choice for non-emergency communication between themselves and the school.

I like emails and I like voice mails at home. At work, I always have my cell phone at work for emergencies, if the school needs to call. We always email back and forth. (The teacher and the parent.) Or, if I have forgotten something or have a question about a project or homework, I can email the teacher and find out what I need to know. So, the school tries to do a lot of things electronically. That's good because it gets it out real quick, and I don't miss it since it comes to me directly through email. If you have a kid that doesn't forget to tell you things, you might prefer that it comes on paper or some other means. I have a boy that always forgets. (Suburban Parent 3, 2012, lines 125-132)

The school and the PTA also maintain linked websites which provide information to parents regarding news, events and activities at the school. Teachers and other personnel at the school maintain classroom websites that are linked to the school's homepage. However, the frequency with which classroom pages are updated varies greatly.

I would say out of all of the teachers maybe 20-30 percent of teachers have strong updated websites that are used. Administration, our counselor, and the $C F$ (curriculum facilitator) do not have one ...I'll be honest with you, I think there's a huge misconception that parents use these, especially in middle and high school. My own middle school child has several different teachers, my high 
school student has six different teachers, and my elementary school student has two. So there's absolutely no way that I, as a parent, have time or could go in and check all of those different sites. At the middle school, there is definitely an expectation that this is what we're doing. And the reality of it is that I'm not. So I ask my child on a regular basis, have you checked all of your teachers' websites. It's almost more a part of his homework routine to go in a check his teachers' websites. I don't do that. (Suburban Principal, 2012, lines 68-79)

Regarding parents use of ICT, they hold a very different view of what constitutes early adoption here than the parents at the other schools in this study. The following exchange between one of the researchers and a parent highlights this difference.

Researcher: When new technology comes out, are you an early adopter? Do you buy it before your friends and neighbors or do you wait until the technology has been around for a while?

Parent: That's hard, because I'm not tech savvy, but I like having it accessible to me. When anything's new, we probably aren't one of the first people to get one.

Researcher: What kind of smartphone do you personally use?

Parent: I have an IPhone.

Researcher: Is your IPhone version 1, 2 or 3?

Parent: (laughing, admits) It's an IPhone 4. We've had smartphones for several years now, and we're a little spoiled with them and couldn't imagine not having them. (Note: At the time of the interview the IPhone 4 was the most current available.)

Another parent offered the following:

My son has an iPhone, against my wishes. I was overruled. He got one on his ninth birthday. He said, 'I've just got to have a phone.' I'd say most of the other kids in his fourth grade class already have smartphones. (Suburban Parent Interview 5, lines 79-83)

This principal's constituents generally have access to a wide variety of new/advanced ICT (see Table 6). They are well-educated, more affluent, and more tech savvy than their counterparts at the other schools. A consequence of this is their high expectations regarding the school's use of ICT.

There are a lot of positives...we have very strong parental involvement. A lot of our parents hold executive type positions and also some have strong technology background, scientific backgrounds--lawyers, and doctors. So there's a lot of pressure to communicate and communicate well. So with our population this (communication) is something that we take seriously. (Suburban Principal, 2012, lines 22-26)

The suburban school has one of the county's most recently renovated facilities, and its traditional brick and white columned building is nestled among tree-lined streets that some locals affectionately refer to as Mayberry, the 1950s sitcom set in a fictional town in North Carolina. Although the principal cites lack of ubiquitous wireless access as an obstacle, the school does have wireless access nodes in the media center, and has some of the district's newest computers, white boards, and other technologies. Parents, however, indicate that the school is woefully behind in technolo- 
gy use, perhaps contributing to the principal's sense that the school's use of ICTs lags behind her parents' expectations and use (Suburban Principal, 2012).

I think they're kind of behind. I think that they're still testing the waters. I would expect that most of this stuff would have happened a few years ago. It seems like maybe in the past few years they've gotten more involved with websites or emails. I think they realize that they kind of have to. I don't know if the change is really a welcomed one, but being in the PTA that was one of our things this year, getting rid of flyers and papers and not sending home all of that stuff. It's a waste of paper and money and going tech is a little bit of an adjustment, because a lot of people don't like it, but we thought it was better. (Suburban Parent Interview 4, lines 232-240)

Table 6: ICT characteristics of parents and principals - high-wealth suburban school

\begin{tabular}{|c|c|c|}
\hline Suburban School & Parents & Principal (or School) \\
\hline $\begin{array}{c}\text { Primary ICT } \\
\text { Preference }\end{array}$ & $\begin{array}{l}\text { MNS* = school news/activities } \\
\text { Email = personal communication } \\
\text { Voice = personal communication } \\
\text { eNewsletter }=\text { school } \\
\text { news/activities } \\
* \text { Mass notification system (MNS) }\end{array}$ & $\begin{array}{l}\text { Email = personal communications } \\
\text { School website = school } \\
\text { news/activities } \\
\text { Teachers' websites = class activities } \\
\text { Voice calls = personal } \\
\text { eNewsletter = school news/activities } \\
\text { Twitter = school news/activities }\end{array}$ \\
\hline ICT Available & $\begin{array}{l}\text { MNS } \\
\text { Email } \\
\text { School website } \\
\text { Teachers' websites } \\
\text { Voice calls } \\
\text { Text msgs. } \\
\text { Social Media } \\
\text { Electronic newsletters } \\
\text { Skype } \\
\text { Twitter }\end{array}$ & $\begin{array}{l}\text { MNS } \\
\text { Email } \\
\text { School website } \\
\text { Teachers' websites } \\
\text { Voice calls } \\
\text { Text msgs. } \\
\text { Social Media } \\
\text { Electronic newsletters } \\
\text { Skype } \\
\text { Twitter }\end{array}$ \\
\hline $\begin{array}{l}\text { ICT Adoption } \\
\text { Characteristics }\end{array}$ & Early Adopters & Early Adopters \\
\hline $\begin{array}{c}\text { Socioeconomic } \\
\text { Status }\end{array}$ & $14 \%$ free or reduced lunch & High-Wealth Suburban School \\
\hline
\end{tabular}

Parents here, particularly those who identified themselves as being heavily engaged at the school as volunteers and active in the PTA, voiced a great deal of dissatisfaction with this principal's leadership and communication - a level of dissatisfaction that the principal was either unaware of, or did not feel comfortable in sharing with the researchers (Affluent School Principal, 2012). These parents seemed to have higher expectations, more intense needs for personalized attention and responsiveness, and less appreciation for the principal's efforts, as well as the efforts of teachers and other school personnel. It is important to note that the other principals had five or more years of experience at their schools at the time of these interviews, and this principal was in her first year at this school (although not new to the principal role), having replaced a popular, longtime administrator who retired and still lives in the community (Hartford County Schools, 2012). 
Though the PTA parents seemed to agree that the principal was not communicating with parents effectively, they did not agree on a solution, or a preferred ICT. For example, one PTA parent indicated dislike for the district's MNS (Affluent School Parent 6, 2012). Another PTA parent voiced concern that the principal did not use it enough, and expressed frustration that the principal did not use any form of communication with consistency. This parent also said that she learned more from the PTA e-newsletter and Facebook postings than from the school principal's communications, while the principal indicated that such communications were sent in partnership with the school, rather than in competition with the school (Suburban Principal Interview, 2012). The principal offered the following:

I think definitely if you were to do a random survey with our 700 families you would definitely find some that would say that if I sent something every single day that it wouldn't be enough and others that would say if I get one more ConnectEd phone call, I'm going to take my entire phone system out. So, there's just such a range. But I would definitely say I hear more and more and more from people about how and when we communicate. I think it's probably just that people want to be involved and we have a lot of working families. So how and when we communicate is sometimes their window into what's happening with their child. (Suburban Principal, 2012, lines 125-131)

Parents who indicated they worked fulltime and/or were less connected with the PTA voiced more satisfaction with the principal, the principal's ICT use and communications efficacy, leading the researchers to question whether the issue was really the principal, the change in administration, or some dysfunction within and among the PTA leadership, who volunteered at the school daily. In many ways, the affluent school's high-demand parents and comparatively large size (713 students compared to 512 at the magnet school and 400 at the urban school) present as complex a communications challenge as the complex and highly diverse student and parent make-up at the low-wealth school.

The data suggests ICT alignment between parents and the principal at the high-income suburban school is mixed. While email is the preferred ICT for the principal and several of the parents interviewed, others expressed frustration that the MNS is not used to communicate weekly news and events at the school. ICT availability is sufficiently high for parents and the principal that it did not seem to be a contributing factor in ICT misalignment. The adoption characteristics of the parents and principal, however, do not seem well-aligned. Although our research team categorizes both parents and principal as early adopters of technology, the principle casts herself and her staff as late adopters. Some of the parents hold a similar view. This seems to reflect the high degree of sophistication of the parents (many of whom have corporate experience) and the principal regarding the potential uses of ICT. The research team categorizes parents and principal as early adopters of technology, with a slight advantage to parents.

\section{District Support for ICT}

One recurrent theme in our interviews with principals was the negative impact of the district's current budget woes and stifling bureaucracy on school ICT use and communications efficacy. Each principal interviewed voiced concern about barriers to ICT use imposed by the district, such as lack of school-wide wireless access to artificial barriers caused by malfunctioning software, hard-to-use systems, excessive legal cautions about using social media, lack of vision, lack of support, and turf battles between schools and central office divisions, and between and among central office divisions. Rather than remove barriers for principals, central office administrators often seem to place more in their way. As the magnet school principal (2012) noted, 
The system doesn't make it easy. I would just say ... <name $>$ is aware of that. She's helped us. I was the bad guy pushing Apple products. And some people within the system actively resisted. And, I mean actively resisted. We just said OK we'll work around you. And we did. It just grew to the point where some people in Tech Services had to relent, but they haven't done it in a supportive way. So I got tired of that battle (lines 284-288)

Similar sentiments were echoed by the principals at the suburban and urban schools, although perhaps to a lesser degree, or more precisely, with less vehemence. At the suburban school, for example, the school and the PTA have purchased projectors, document cameras, and other hightech tools, but teachers cannot use these in the classrooms because the school only has a few wireless nodes. Video downloads teachers would like to use for instructional purposes get blocked by the school system's Internet filters, ostensibly due to CIPA and COPA (Child Internet and Child Online Protection Act) regulations, and teachers find the district's content management system for website development hard to use, even though the state's new teacher evaluation system holds teachers accountable for integrating technology into instruction. Teachers and principals are also routinely blocked from accessing social media outlets like Facebook, Twitter, Tumblr, and other sites as well as 21 st century tools that can be used for communicating with parents as well as for instructional purposes. When the principal at the suburban school questioned these practices, the information services department contacted her and indicated they would provide access to social media for instructional purposes, as long as she signed an individual permission slip for each of her staff on an annual basis.

So I was like really? How much time is it going to take me to sign fifty plus pieces of paper each year for you guys to relinquish this power? So, there are definitely barriers. I think there are a lot of people who want to do more but we feel like we can't. (Suburban Principal, 2012, lines 163-170)

For the principal of the low-wealth schools, the issues are similar, yet different, as the concerns center on the slow pace of one-to-one technology adoption compared to the social justice aspect of giving parents and students living in poverty access to tools that will help them learn and compete in a global society. As the urban principal noted, "So, it's a process and we're taking one little thing at a time" (lines 212-213). Unlike the magnet school and suburban school, where parents have high expectations regarding ICT use and the availability of 21 st century learning tools in the classroom and at home, the urban school parents did not make similar demands. As the urban principal noted,

I was disappointed, for example, at first with Parent-Assist I thought more parents would be excited about checking their children's grades online, and we promoted it and encouraged them to use it. We even set up stations where they could do it at school and find out, but it still has been slow going. I think that I still have a majority of my parents that are more comfortable with traditional means of communication. (lines 195-199)

We find high variability between the three schools regarding the ICT characteristics of parents and principals, the alignment of these characteristics, and the perceived effectiveness of communications between the school and home. Unsurprisingly, our study finds the highest degree of ICT alignment and communications efficacy at the magnet school, whose focus is on science and technology. Here, parents are early majority adopters of ICT and the principal and his staff are early adopters and innovators. Parents express a high degree of satisfaction regarding their communication with this principal and his staff and describe communications as very effective. ICT alignment was mixed at the low-wealth urban school. The principal at this school struggles to 
increase parental use of computers and the Internet. However, many parents who do not have access to the Internet from home rely on text messaging through their cellphones for ICT communications. Text messaging is not yet used by the school. Though the principal and her staff spend considerable effort to increase communications efficacy at the low-wealth urban school, there is room for improvement. ICT alignment between parents and the principal at the high-income suburban school is also mixed. While email is the preferred ICT for the principal and several of the parents interviewed, others expressed frustration that the MNS is not used to communicate weekly news and events at the school. Although our research team categorizes both parents and principal as early adopters of technology, the principle and many of the parents hold a different view.

They cast the principal and her staff as late adopters. This dissonance seems to be a consequence of the high expectation by the parents and principal regarding the full potential of ICT. Both parents and principal believe there is room to improve the efficacy of communication through better use of ICT.

\section{Discussion}

One thing apparent from the interviews was the subjective nature of the interviewees' perceptions regarding adoption and diffusion of ICT. The principal at the urban low-wealth school, for example, characterized herself and her staff as early adopters of technology, even though her use of ICTs was relatively limited, and consisted primarily of deploying the district's MNS (Urban School Principal, 2012). She and her staff teach disadvantaged parents how to use ICT, including the Internet and email, to check their children's grades, search for jobs and housing options, and find out about community resources. Her self-characterization appears to be linked to the high percentage of non-adopters and late adopters who are her constituents. However, she and her staff are late adopters relative to their peers at other schools. Similarly, the principal at the high-wealth suburban school miscasts herself as a late adopter of ICT, though the evidence from the case indicates she is in fact an early adopter of ICT relative to her peers at other schools. She has demonstrated considerable sophistication regarding the use of ICT; for example, creating html-based electronic newsletters which are attractive and informative, and delivering them on a weekly basis to her constituents via email. Like the principal at the low-wealth urban school, her selfcategorization appears to be linked to the ICT capabilities and high expectations of the parents with whom she communicates. In addition to misperceptions of their adoption posture, both schools suffer some degree of misalignment in the ICT preferences of the parents and principals, which is negatively impacting communications efficacy, as indicated by parent and principal interviews. In contrast, at the magnet school, the principal accurately categorizes himself as an early adopter of ICT. He and his staff are innovative in their use of ICT to facilitate communication and engagement with parents and students. Our data supports the view that there is a high degree of ICT alignment between the parents and the principal and his staff, and there is a high degree of satisfaction regarding communications efficacy.

These findings support the conceptual framework outlined in Figure 2 where greater alignment across the principal-parent dyad between ICT preferences, availability, diffusion adoption characteristics, and socioeconomic status yields greater communication efficacy. However, one unexpected finding of the study is that higher degrees of parental engagement were associated with higher degrees of parental dissatisfaction. This finding is both unexpected and potentially significant, especially as public schools and school systems increasingly compete in a choice-driven marketplace where parental and community perceptions often drive enrollment. Communication research and educational leadership literature typically indicate that higher degrees of engagement generate higher levels of parental satisfaction as well as better outcomes for students, not less (Cary, 2006; Henderson \& Mapp, 2002). At this point, it is unclear whether the root cause is ICT misalignment, communications misalignment, resistance to the change in leadership at this particular school, an emerging trend in high wealth schools, especially in a choice and hence, 
consumer-driven marketplace, a unique cluster of personalities, or something else entirely. These questions could form the basis of future research studies.

The complexity of the environment in which principals operate and the communication challenges faced by each of the principals interviewed for this study also merits further research. While parents across all sectors still indicate a preference for personal, face-to-face communications and other traditional methods, their expectations for tailor-made solutions that fit their individual families' needs, preferences, and lifestyles - and the resulting expertise, ICT sophistication, and time such individualized communication requires - represents a neglected area of research in educational leadership. Parents need differentiated communications as much as students need differentiated instructional support. It is important to note, for example, that while one parent at the lowwealth urban school did not know what a smart phone was, another parent at the same school was a professional in a high-tech industry. As government entities that rely almost exclusively on tax dollars for funding, most public schools are not staffed or equipped to create, deploy and manage such complex communication campaigns and marketing initiatives, especially during a down economy in which every dollar spent gets additional scrutiny. While private schools and many charter schools include student recruiters, fund development experts, and parent outreach coordinators on their payrolls, most public schools do not, except perhaps in limited fashion at the district level.

While not the focus of this study, parent interviewees at all schools mentioned active charter school recruitment and marketing efforts targeting their children, or other children enrolled at the schools studied. Charter schools, in the U.S., are publicly funded schools that are not governed by the local school board. Instead, they operate under legislative contracts (or charters) with state or local governments. They are exempted from certain rules and regulations and, in exchange for this flexibility, are required to meet accountability standards specified in their charter. School charters can be revoked if guidelines on curriculum and management are not followed or agreedupon standards are not met. One of the more disgruntled PTA parents at the suburban school said she was concerned about a proposed charter school planned for their community as she anticipated it would compete with the PTA's fundraising efforts on behalf of the suburban school and might hurt enrollment - and result in an additional loss of funds above and beyond state budget cuts (Affluent School Parent 1, 2012). In addition to the suburban school parent's unusual understanding of how public schools are funded, her negative experiences in California with the impact of school choice and inadequate funding of public schools offered keen insights into potential future struggles for this region and state, which only recently lifted the cap on charter schools. Such angst about increasing competition could be driving the parents' concerns regarding the quality and quantity of communications at their children's suburban school, which they clearly are deeply supportive of, despite their grumblings. Again, these issues go beyond the scope of this study on ICT use in school-home communications, but certainly merit additional research.

The finding that bureaucratic obstacles are often more challenging and difficult to deal with than parent-driven issues, while consistent with school transformation literature, also points to significant changes that must be made at the district level, especially as school systems must become more nimble, flexible, and school-centered if all schools are going to reach higher levels of performance. The new market pressures created by the privatization of public schools and the deregulation of all but traditional public schools in the U.S. have significant implications for change for central office structures, which must shift from hierarchical, tradition-bound organizations to more flexible service and support systems in order to survive. As systems struggle to find the right balance between site based management approaches, which yield only school-by-school improvements and pockets of excellence, versus system-wide transformational improvements, the pressure to remove bureaucratic barriers will only increase. ICTs and other technological innovations can play an important role in improving organizational as well as communication efficacy, 
but only if district leaders, including superintendents and school boards, have the vision to see what is possible and the will to make the necessary structural and personnel changes. Otherwise, the clamor for more parental control and consumer-driven choices will only likely increase, leaving students and parents at urban schools like the ones examined in this study lagging even further behind their more affluent and highly educated counterparts. These issues merit further study and debate, both in the academic and public policy arenas. Currently, few models exist of systemwide transformation, even though the dissatisfaction with 30 years of school-by-school reform is widespread and extant in the literature (Duffy, 2010).

\section{Conclusion}

Research presented in this paper explores the relatively unexplored role of parents and principals ICT alignment on the efficacy of school/home communications. Our qualitative investigation of ICT alignment and communications efficacy at three different public elementary schools (suburban/high wealth; urban/low wealth; urban magnet/mixed income) reveals misperceptions by parents and principals at two of the three schools regarding their ICT adoption beliefs and actual use. We find misalignment in the ICT preferences of the parents and principals at these schools as well. Our results support our theoretic framework (see Figure 2) and indicate alignment between parent and principal ICT preferences and expectations positively impacts communications efficacy between the parent and the school, while misalignment has the opposite effect. Study findings indicate that ICT alignment between parents and principals improves parent satisfaction with the principal and the school, whereas misalignment seems to have the opposite effect.

The study makes contributions to theory and practice. First, we develop a theoretically and empirically informed model of ICT alignment, based on Rogers (2003) diffusion of innovation theory, which examines the role of ICT alignment between parents and principals on communications efficacy. We believe this framework extends the concepts of diffusion of innovation and two-way communications symmetry theory to provide a conceptual framework for researching schoolhome communications in general. Second, this research informs the strategic selection of ICT by school administrators and principals. Understanding parent and principal differences and preferences when developing and deploying strategic communication plans represents a key leadership management function for educational leaders today (Cary, 2006).

It is important to note that this research is subject to several limitations. First, all of the subjects interviewed in this study were drawn from the same geographic region of the U.S. Therefore, the perceptions and expectations of parents, principals and school administration are shaped by regional customs, laws and cultural influences. Consequently, the findings must be interpreted in this light. Second, as with all qualitative research, the process of explanation building is somewhat subjective and subject to researcher bias. As researchers, we have remained aware of this possibility and worked diligently to minimize its impact. All of the investigators discussed their findings with one another and reached consensus on conclusions which are inclusive and reflective of all evidence collected. Finally, this study relies on matched interviews to understand the impact of ICT on parent/principal communications. Once principal interviewees had been identified, they were engaged in helping the researchers identify a diverse group of parents from each school, including those visibly active at school and those who are not. Principal involvement introduces the possibility of sampling bias in the parents interviewed. However, the research team found no evidence of this, as the parents interviewed were often critical of principals' leadership and communication.

By building a more in-depth understanding of the influences of ICT diffusion, preferences, and habits of parents and principals on their communication, we hope this study can inform professional practice and invite future research at the confluence of educational leadership, communications, and information technologies. 


\section{References}

Askar, A. H. H. (2013). The effect of parental involvement on esl students' achievement and classroom behavior. MSc Thesis. Retrieved from http:/bspace/buid.ac.ae/handle/1234/405

Bryk, A., \& Schneider, B. (2002). Trust in schools: A core resource for reform. Educational Leadership, $60(6), 40-45$.

Carr, N. (2006). Going direct. American School Board Journal, 194(1), 59-60.

Carr, N. (2010). Don't wait - act. American School Board Journal, 198(2), 24-26.

Carr, N. (2012). Using technology for school communications: GCS doctoral cohort survey 2012: Analysis and implications, recommendations, tools. Retrieved from https://libres.uncg.edu/ir/uncg/ listing.aspx?styp=ti\&id $=18072$

Cary, A. O. (2006). How strong communication contributes to student and school success: Parent and family involvement. Rockville, MD: The National School Public Relations Association.

Chaboudy, R., \& Jameson, P. (2001). Connecting families and schools through technology. The Book Report, 20(2), 52-57.

Creswell, J. W. (1998). Qualitative inquiry and research design choosing among five traditions. Thousand Oaks, CA: Sage Publications.

DeFur, S. (2012). Parents as collaborators: Building partnerships with school and community based providers. Teaching Exceptional Children, 44(3), 58-67.

De Gaetano, Y. (2007). The role of culture in engaging Latino parents' involvement in school. Urban Education, 42(2), 145-162.

The Department for Education and Skills (DfES). (2003). The impact of parental involvement on children's education. London: DfES.

Driessen, G., Smit, F., \& Sleegers, P. (2005). Parental involvement and educational achievement. British Educational Research Journal, 31(4), 509-532.

Duffy, F. M. (2010). Dream! Create! Sustain!: Mastering the art and science of transforming school systems. Lanham, MD: Rowman \& Littlefield Education.

Flessa, J. (2008). Parental involvement: What counts, who counts it, and does it help? Education Canada, $48(2), 18-21$.

Gonzalez-DeHass, A. R., Willems, P. P., \& Doan Holbein, M. F. (2005). Examining the relationship between parental involvement and student motivation. Education Psychology Review, 17(1), 99-123.

Grant, L. (2011). 'I'm a completely different person at home': Using digital technologies to connect learning between home and school. Journal of Computer Assisted Learning, 27(4), 292-302.

Grunig, J. E., \& Grunig, L. A. (1992). Models of public relations and communication. In J. E. Grunig (Ed.), Excellence in public relations and communication management (pp 285-325). Hillsdale, NJ: Lawrence Erlbaum Associates.

Guion, L. A., Diehl, D. C., \& McDonald, D. (2011). Triangulation: Establishing the validity of qualitative studies, Publication\# FCS6014. Retrieved from University of Florida IFAS extension https://edis.ifas.ufl.edu/fy394

Hartford County Schools. (2012). Hartford County Schools - Thriving, achieving, excellence. Retrieved from www.gcsnc.com

Hayes, H. (2011). Predicting parental home and school involvement in high school African American adolescents. The High School Journal, 94(4), 154-166.

Henderson, A. T., \& Mapp, K. (2002). A new wave of evidence: The impact of school, family and community connections on student achievement. Austin, TX: Southwest Educational Development Laboratory. Retrieved from https://www.sedl.org/connections/resources/evidence.pdf 
Hill, N. E., Castellino, D. R., Lansford, J. E., Nowlin, P., Dodge, K. A., Bates, J. E., \& Pettit, G. S. (2004). Parent academic involvement as related to school behavior, achievement, and aspirations: Demographic variations across adolescence. Child Development, 75(5), 1491-1509.

Huang, Y. H. (2004). Is symmetrical communication ethical and effective? Journal of Business Ethics, 53(4), 333-352.

Jeynes, W. H. (2007). The relationship between parental involvement and urban secondary school student academic achievement: A meta-analysis. Urban Education, 42 (1), 82-110.

Joshi, A., Eberly, J., \& Konzal, J. (2005). Dialogue across cultures: Teachers' perceptions about communication with diverse families. Multicultural Education, 13(2), 11-15.

Kent, M. L., \& Taylor, M. (2002). Toward a dialogic theory of public relations. Public Relations Review, 28(1), 21-37.

Lenhart, A., Purcell, K., Smith, A., \& Zickulu, K (2010). Social media and mobile internet use among teens and young adults. Retrieved from Pew Internet \& American Life site: http://www.pewinternet.org/ files/old-media/Files/Reports/2010/PIP_Social_Media_and_Young_Adults_Report Final with toplines.pdf

Louis, K. S., \& Wahlstrom, K. (2011). Principals as cultural leaders. Phi Delta Kappan, 92(5), 52-56.

Machen, S. S., Wilson, J. D., \& Notar, C. E. (2005). Parental involvement in the classroom. Journal of Instructional Psychology, 32(1), 13-16.

Murphy, T. (2013). An evaluation of home-school partnership relations developed in designated disadvantaged (DEIS) post-primary schools to enhance students' literacy and numeracy. DEd Thesis. Retrieved from http://doras.dcu.ie

Noonan, B., Walker, K., \& Kutsyuruba, B. (2008). Trust in the contemporary principalship. Canadian Journal of Educational Administration and Policy, 85, 1-17.

Pavlik, J. V. (2007). Mapping the consequences of technology on public relations. Retrieved from http://www.instituteforpr.org/mapping-technology-consequences/

Rogers, E. M. (2003). Diffusion of innovation (5th ed.). New York: Free Press.

Selwyn, N. (2004). Reconsidering political and popular understandings of the digital divide. New Media \& Society, 6(3), 341-362.

Shirvani, H. (2007). Effects of teacher communication on parents' attitudes and their children's behaviours at schools. Education, 128(1), 34.

Singhal, A., \& Rogers, E. M. (2001). The entertainment-education strategy in communication campaigns. Public communication campaigns, 343-356, Thousand Oaks, CA: Sage Publications.

Springston, J. K. (2001). Public relations and new media technology: The impact of the internet. Handbook of Public Relations, 583-589, Thousand Oaks, CA: Sage Publications.

Thompson, R. A., \& Raikes, H. A. (2007). The social and emotional foundations of school readiness. Social and emotional health in early childhood: Building bridges between services and systems, 13-36, Baltimore: Brookes.

Tschannen-Moran, M. (2004). Trust mailers: Leadership for successful schools. San Francisco, CA: Jossey Bass.

U.S. Census Bureau. (2012). QuickFacts. Retrieved from http://quickfacts.census.gov

Wiseman, A. (2010). Family involvement in four voices: Administrator, teacher, students, and community member. Penn GSE Perspectives on Urban Education, 7(1), 115-124.

Wright, D. K. (2001). The magic communication machine: examining the Internet's impact on public relations, journalism, and the public. Retrieved from http://www.instituteforpr.org/wp-content/ uploads/2001_InternetImpact.pdf

Zickurh, K. (2013). Who's not online and why? Retrieved from Pew Internet \& American Life site: http://www.pewinternet.org/2013/09/25/main-report-2/ 
Heath, Maghrabi, \& Carr

\section{Appendix: \\ Overview of the Semi-structured Interview's Protocol}

PRE-INTERVIEW

- Introduce self and role

- Thank participant for willingness to share their ideas with you

- Purpose of the Study: To determine whether and how new ICTs are affecting homeschool communications between principals and parents.

- Assure/remind participant of confidentiality and anonymity; briefly explain how data will be collected, analyzed and used

- Secure signed/written consent

- Note relevant and voluntary demographic either at beginning or end of interview; with parents, it is often better to ask demographic questions at the end of interview. Gender, Age Range, Race/Ethnicity. Socioeconomic status will be inferred generally from student demographic data for each school provided through public sources.

\section{PRINCIPAL INTERVIEW QUESTIONS}

1. Why don't you tell me a little about yourself and your school?

2. What ways work best when communicating with your school parents about:

a) general school news, events, deadlines and information?

b) their child's work/progress?

c) problems or concerns at school?

d) problems or concerns involving their child?

e) other topics or issues?

3. What communication technologies are available to you at your school? Probe for social media, websites, podcasts, video streaming, MNSs, mobile technologies, etc.

4. Are there communication technologies you have at home that you'd like to have at school? If so, which ones and why?

5. How would you rate your school's adoption of new technologies? (Probe for early adopter, early majority, majority, laggard, or other indicators.)

6. What role does technology play in communicating with parents? Which technologies do you prefer to use, and why?

7. What barriers get in the way of effective school-home communications?

8. How do you think school-home communication can be improved?

9. What communication technologies or methods would you like to use but can't currently?

10. What's getting in the way of you using these technologies or methods? (Probe for technology, access, cost, training issues)

11. What do you wish parents understood more about school-home communication?

12. Do you have example of a best practice of using technology for school-home communication that you'd like to share?

13. Overall, does technology help or hinder school-home communication? Probe for explanation.

14. Is there anything we didn't think to ask you about school-home communication and the use of communication technologies that we didn't think to ask you?

\section{PARENT INTERVIEW QUESTIONS}

1. Why don't you tell me a little about yourself and your child/children? Your child's school?

2. How do you prefer the principal and/or school personnel communicate with you about:

a) general school news, events, deadlines and information?

b) their child's work/progress?

c) problems or concerns at school? 
d) problems or concerns involving their child?

e) other topics or issues?

3. Is there any type of information that you're not currently getting, or topics that you'd like more information about, that you'd like more communication about? If so, please describe.

4. What communication technologies are available to you at home? What communication technologies are available to you at work or through other means? (Probe for Internet access, social media, websites, podcasts, video streaming, MNSs, mobile technologies, etc.).

5. What role does technology play in communicating with you as a parent of school-aged children? Which technologies do you prefer to use, and why?

6. Are there technologies you have at home or at work that you wish the principal/school personnel would use more frequently? Less frequently? (Probe for which ones and why.)

7. What barriers get in the way of effective school-home communications?

8. How do you think school-home communication can be improved?

9. What communication technologies or methods would you like to use but can't currently?

10. What's getting III the way of you using these tec1mologies or methods? (Probe for technology, access, cost, training issues)

11. What do you wish principals and other school personnel understood more about school-home communication?

12. Do you have a great example of how your principal or other school personnel are using technology for school-home communication that you'd like to share? Do you have an example of how other organizations or companies communicate with you that you'd like schools to do as well?

13. Overall, does technology help or hinder school-home communication? Probe for explanation.

14. Is there anything we didn't think to ask you about school-home communication and the use of communication technologies that we didn't think to ask? 


\section{Biographies}

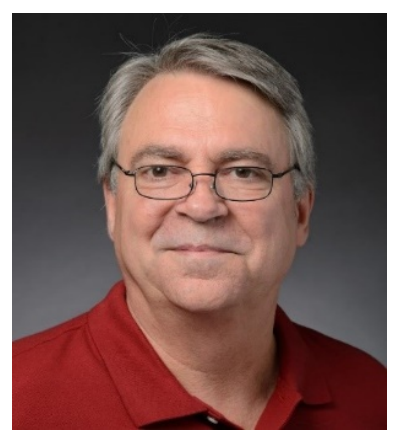

Don Heath is an Assistant Professor of Information Systems in the College of Business at the University of Wisconsin Oshkosh. He holds a PhD in Information Systems from the Bryan School of Business and Economics at the University of North Carolina at Greensboro. His research interests include social media engagement by organizations and computer-mediated social interaction. He has published his research on social media engagement by organizations in academic journals and presented his research at national and international conferences. He regularly consults with industry on how to leverage ICT to maximize social engagement.

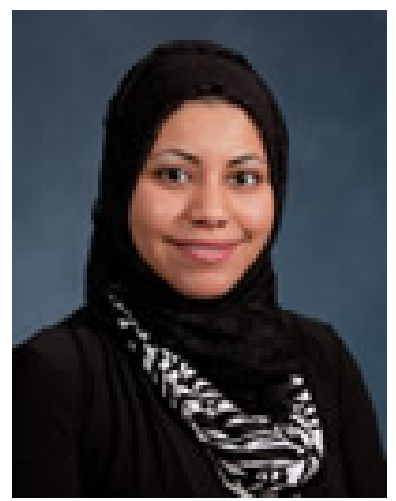

Ms. Rozan Maghrabi is a $\mathrm{PhD}$ candidate at the University of North Carolina at Greensboro. She holds a MS in Information Technology Management. She received her BS in Business Administration from King Abdul Aziz University, Saudi Arabia. She has published research in journals such as Computers in Human Behavior journal on social capital in social media. She has presented research on social media and social interactions at conferences, including the Global Information Technology Management Association World Conference (GITMA), Americas Conference on Information Systems (AMCIS) and in the premier International Conference on Information Systems (ICIS). She recently co-authored a research project with Dr. Nir Kshetri titled, "The Development of the M-Commerce Industry in the Gulf Cooperation Council Economies: An Institutional Analysis". She participated in the 2009 International Conference on IS and Economic Intelligence held in Sousse, Tunisia.

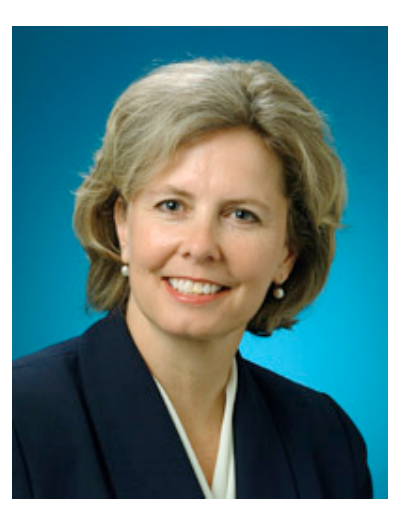

Nora Carr is the chief of staff for Guilford County Schools. Carr has won more than 90 local, state and national awards for communications excellence. In 2008, she was accepted into the College of Fellows of the Public Relations Society of America, an honor bestowed only on the nation's leading public relations professionals. In her 27-year career, Carr has worked as a professional communicator, providing guidance on issues management, communications and strategic planning to hospitals, school districts and educational associations. She has served as assistant superintendent for public information at CharlotteMecklenburg Schools, as well as chief communications officer. Carr holds a Bachelor of Arts degree in English from St. Louis University and a Master of Arts degree in communication studies from the University of North Carolina at Charlotte. She is accredited in public relations (APR) by the Universal Accreditation Board. 